\title{
Non-Genetic Factors Effecting Reproduction Traits in Rambouillet Sheep
}

\author{
N.N. $\operatorname{Khan}^{1} *$, N. Assad ${ }^{2}$, Nishant Kumar ${ }^{3}$, D. Chakraborty $^{3}$, Aadil Ayaz ${ }^{4}$, \\ Aarif $\mathrm{Ali}^{5}$, Mashooq Ahmad Dar ${ }^{5}$ and Suheel Yousuf Wani ${ }^{1}$ \\ ${ }^{1}$ Division of Animal Genetics and Breeding, Faculty of Veterinary Sciences and Animal \\ Husbandry Sher-e-Kashmir University of Agriculture Sciences and Technology Shuhama \\ Alustang Kashmir 190006, India \\ ${ }^{2}$ Animal Husbandry Department, J\&K, India \\ ${ }^{3}$ Division of Animal Genetics and Breeding SKUAST Jammu, India \\ ${ }^{4}$ Department of Zoology and Biotechnology, Hemwati Nandan Bahuguna Garhwal University \\ Uttrakhand India, 246174 \\ ${ }^{5}$ Department of Biochemistry University of Kashmir, Jammu and Kashmir, India \\ *Corresponding author
}

\begin{tabular}{|c|c|}
\hline & A B S T R A C T \\
\hline & \multirow{4}{*}{$\begin{array}{l}\text { A total of } 4186 \text { records of Rambouillet sheep maintained at Government Sheep } \\
\text { Breeding and Research Farm, Reasi, Jammu, India for } 10 \text { years (1998-2007) were } \\
\text { analyzed to estimate the reproduction traits in relation to non-genetic factors viz., } \\
\text { season of lambing and year of lambing on Age at first fertile service, Age at first } \\
\text { lambing, litter size at birth and interlambing period. The overall mean for Age at } \\
\text { first fertile service (AFFS), Age at first lambing (AFL), litter size at birth (LS) and } \\
\text { interlambing period (ILP) were } 727.17 \pm 2.03 \text { days, } 877.04 \pm 2.01 \text { days, } 1.05 \pm 0.00 \text {, } \\
\text { and } 368.34 \pm 0.22 \text { days with corresponding coefficient of variations } 12.40 \% \text {, } \\
10.21 \% 21.51 \% \text { and } 2.67 \% \text {, respectively. In present study, year and season had } \\
\text { non- significant effect on AFFS, AFL, LS and ILP. }\end{array}$} \\
\hline $\begin{array}{l}\text { Non-genetic } \\
\text { factors, } \\
\text { Reproduction, } \\
\text { Rambouillet } \\
\text { Sheep. }\end{array}$ & \\
\hline Article Info & \\
\hline $\begin{array}{l}\text { Accepted: } \\
\text { 29 June } 2017 \\
\text { Available Online: } \\
\text { 10 August } 2017\end{array}$ & \\
\hline
\end{tabular}

\section{Introduction}

Rambouillet is well known breed due to its excellence in maternal ability. It is the largest fine wool breed adaptable to wide variety of arid range conditions, has a well-developed flocking instinct and is long lived. The breed, although originally developed in France as a wool breed, after importation in the mid 1800s (Dickson et al., 1933), was developed into a dual-purpose breed in the U.S. (Hultz et al., 1931). The breed is also well known for its meat. Rambouillet is intensively used for cross breeding programme in India for improving the productivity of native sheep. Reproductive characteristics have been recognized as main factors affecting profitability of sheep breeding systems (Matos et al., 1997). Therefore, improvement in ewe productivity is a key target in sheep breeding and could be attained to some extent by increasing the number of lambs weaned and weight of lambs weaned per ewe within a specific year (Duguma et al., 2002). The 
major part of the income in any sheep production system is supplied through lamb production (Ekiz et al., 2005). Profitable wool and mutton production and faster genetic progress of sheep flock are mainly dependent on higher degree of reproductive efficiency of breedable ewes. The economics of sheep farming is based not only the characters of wool and mutton production alone but also on ewes efficient reproduction performance. Failure to maintain sufficiently higher degree of reproductive efficiency is the major economic loss to the sheep husbandry.

\section{Materials and Methods}

The data were obtained from the records of 4186 Rambouillet sheep maintained at Government Sheep Breeding and Research Farm, Reasi, Jammu, India. The data were spread over a period of ten years i.e. from 1998 to 2007. The reproduction traits studied were age at first fertile service, age at first lambing, litter size at birth and interlambing period. The mean, standard errors and coefficient of variations (CV) were computed statistically. The effects of non-genetic factors such as years and seasons on these reproduction traits were analyzed by least squares analysis using the technique developed by Harvey (1990). The following model was used for present investigation with assumptions that the different components being fitted into the model were linear, independent and additive.

$$
\mathrm{Y}_{\mathrm{ijklm}}=\mu+\mathrm{R}_{\mathrm{i}}+\mathrm{Y}_{\mathrm{j}}+\mathrm{S}_{\mathrm{k}}+\mathrm{e}_{\mathrm{ijkl}}
$$

Where,

$Y_{i j k l m}=m^{\text {th }}$ record of individual of $i^{\text {th }}$ Ram lambed in $\mathrm{j}^{\text {th }}$ year, $\mathrm{k}^{\text {th }}$ season and

$\mu=$ Overall population mean

$\mathrm{R}_{\mathrm{i}}=$ Random effect of $i^{\text {th }}$ ram

$\mathrm{Y}_{\mathrm{j}} \quad=\quad$ Fixed effect of $\mathrm{j}^{\text {th }}$ year of $\mathrm{S}_{\mathrm{k}}=$ Fixed effect of $\mathrm{k}^{\text {th }}$ season of lambing $\mathrm{e}_{\mathrm{ijkl}}=$ Error associated with each observation and assume to be normally and independently distributed with mean zero and variance $(0$, $\left.\sigma_{\mathrm{e}}^{2}\right)$

The least square means of significant effects were compared using Duncan's multiple range test (DMRT) as modified by Kramer (1957).

\section{Results and Discussion}

The average estimates of reproduction traits viz. AFFS, AFL, LS, and ILP along with standard errors (S.E), standard deviations (SD) and coefficient of variation $(\mathrm{CV} \%)$ are presented in table 1 . The least square means for AFFS, AFL, LS, and ILP along with their standard errors are presented in table 2 and ANOVA in table 3. The overall mean of age at first fertile service in present investigation was estimated as $727.17 \pm 2.03$ days and falls within the range of $707.00 \pm 42.0$ days reported by Arora et al., (1978) in Malpura and Chokla breed of sheep. Lower estimates ranged from $583.02 \pm 1.05$ days to $639.1 \pm 15.94$ days were reported by Bohra (1993), Khan et al., (2002), and Babar and Javed (2009) in Rambouillet breed of sheep. Higher estimate of $819.68 \pm$ 70.52 days was reported by Jain et al., (2001) in Rambouillet breed of sheep. The coefficient of variation of AFFS was low (12.40) indicating that the trait had low variability. The overall mean of age at first lambing in present investigation was estimated as $877.04 \pm 2.01$ days. It is in close agreement with the findings (967.3 \pm 25.5 days) of Bohra (1993) in Rambouillet breed of sheep. Lower estimate of $735.67 \pm 1.13$ days was reported by Khan et al., (2002) in Rambouillet breed of sheep. Higher estimates of $1009 \pm 38$ and $1030 \pm 20.07$ days were reported by Arora et al (1978) in Malpura and Chokla. The coefficient of variation of AFL was low (10.21) indicating that the trait had low variability. The overall mean of litter size 
in present investigation was estimated as $1.05 \pm 0.00$ which were very close to the average litter size reported by Ferda et al., (2009) in Fat tailed sheep. Higher estimates were reported by Shaoqi Rao (1997) in Suffolk, Targhee and Polypay breeds of sheep. The overall mean of inter lambing period in present investigation was estimated as $368.34 \pm 0.22$ days which were very close to the average inter lambing period of $370.70 \pm 1.09$ days reported by Jain et al., (2001) in Rambouillet breed of sheep. Lower estimates were reported by Gonzalez et al., (1986) in Merino, Lehnherr (1990) in Swiss White Alpine breed of sheep. Higher estimates were reported by Khan et al., (2002) in Rambouillet, and Babar and Javed (2009) in Rambouillet breed of sheep. The coefficient of variation of ILP was low (2.67) indicating that the trait had low variability.

The effect of year of birth was non-significant on age at first fertile service. No literature was available as concerned regarding the nonsignificant effect of year on age at first fertile service. However significant effect of year on age at first fertile service was reported by Narayanswamy et al., (1976) in Mandya sheep, Kabuga and Akowuah (1991) in Djallonke and Sahel sheep, Jain et al., (2000) in Rambouillet, and Khan et al., (2002) in Rambouillet and Kaghani sheep

The effect of season of birth was nonsignificant on age at first fertile service. Similar findings were reported by Babar and
Javed (2009) in Rambouillet. On contrary significant effect of season of birth on age at first fertile service was reported by Sinha (1996) in Muzaffarnagri and their crosses with Dorset and Suffolk, Jain et al., (2000) in Rambouillet, and Khan et al., (2002) in Rambouillet and Kaghani sheep. The effect of year of birth was non-significant on age at first lambing. Similar findings were reported by Kaul (1979) in Muzaffarnagri, Tamu (1980) in Rambouillet, and Babar and Javed (2009) in Rambouillet. On contrary significant effect of season of birth on age at first lambing was reported by Malik et al., (1978) in Rambouilet with chokla, Malpura and Jaisalmeri, and Narayanswamy (1978) in Bannur sheep, and Gabina et al., (1990) in Lacha ewes. The effect of season of birth was non-significant on age at first lambing. Similar findings were reported by by Tamu (1980) in Rambouillet. On contrary significant effect of season of birth on age at first lambing was reported by Narayanswamy (1978) in Bannur sheep, and Sinha (1996) in Muzaffarnagri and their crosses with Dorset and Suffolk. The effect of year of birth was highly significant $(\mathrm{P}<0.01)$ on litter size. Similar findings were reported by Trejo et al., (1990) in Chalma sheep, Molina et al., (1991) in Manchega sheep, Shelton et al., (1991) in Rambouillet and Mokhlari et al., (2010) in Kermani sheep. The effect of season of birth was non-significant on litter size. No literature was available as concerned regarding the non-significant effect of season on litter size.

Table.1 Average estimates along with standard errors of reproduction traits

\begin{tabular}{|l|l|l|l|l|}
\hline TRAITS & $\begin{array}{l}\text { Number of } \\
\text { observations }\end{array}$ & Mean \pm SE & $\begin{array}{l}\text { Standard } \\
\text { deviation }\end{array}$ & $\begin{array}{l}\text { CV } \\
(\boldsymbol{\%})\end{array}$ \\
\hline AFFS(days) & 1976 & $727.17 \pm 2.03$ & 90.21 & 12.40 \\
\hline AFL(days) & 1976 & $877.04 \pm 2.01$ & 89.62 & 10.21 \\
\hline LS & 4186 & $1.05 \pm 0.00$ & 0.22 & 21.51 \\
\hline ILP(days) & 1976 & $368.34 \pm 0.22$ & 9.84 & 2.67 \\
\hline
\end{tabular}


Int.J.Curr.Microbiol.App.Sci (2017) 6(8): 3698-3704

Table.2 Analysis of variance for reproduction traits in Rambouillet sheep

\begin{tabular}{|c|c|c|c|c|}
\hline Sources of variation & & $\mathbf{M}$ & & \\
\hline & AFFS & AFL & $\mathbf{L S}$ & ILP \\
\hline Season of lambing & $\begin{array}{c}2740.82 \\
(1)\end{array}$ & $\begin{array}{r}4097.04 \\
(1)\end{array}$ & $\begin{array}{r}0.0018 \\
(1)\end{array}$ & $\begin{array}{r}23.27 \\
(1)\end{array}$ \\
\hline Year of lambing & $\begin{array}{r}6919.11 \\
(9)\end{array}$ & $\begin{array}{r}7374.98 \\
(9)\end{array}$ & $\begin{array}{r}0.22^{* *} \\
(9)\end{array}$ & $\begin{array}{r}46.78 \\
(9)\end{array}$ \\
\hline Sex & - & - & $\begin{array}{c}0.03 \\
(1)\end{array}$ & - \\
\hline Residual/ Error & 8148.16 & 4097.04 & 0.05 & 97.27 \\
\hline
\end{tabular}


Table.3 Least squares mean for various non-genetic factors influencing reproduction traits in Rambouillet sheep

\begin{tabular}{|c|c|c|c|c|}
\hline Particulars & AFSS mean \pm SE $(x)$ & AFL mean \pm SE $(x)$ & LS mean \pm SE $(x)$ & ILP mean \pm SE $(x)$ \\
\hline Overall mean & $724.02 \pm 4.96(1976)$ & $873.40 \pm 4.92(1976)$ & $1.05 \pm 0.00(4186)$ & $\begin{array}{c}368.48 \pm 0.54 \\
(1976)\end{array}$ \\
\hline Year & NS & NS & $* *$ & NS \\
\hline 1998 & $723.44 \pm 7.56(208)$ & $871.73 \pm 7.51(208)$ & $1.07 \pm 0.01^{\mathrm{cd}}(503)$ & $368.99 \pm 0.82(208)$ \\
\hline 1999 & $730.80 \pm 6.65(269)$ & $880.69 \pm 6.60(269)$ & $1.06 \pm 0.01^{\text {bcd }}(556)$ & $368.93 \pm 0.72(269)$ \\
\hline 2000 & $726.59 \pm 7.24(260)$ & $875.09 \pm 7.19(260)$ & $1.09 \pm 0.01^{\mathrm{d}}(518)$ & $368.51 \pm 0.79(260)$ \\
\hline 2001 & $714.37 \pm 8.01(196)$ & $862.65 \pm 7.96(196)$ & $1.02 \pm 0.01^{\mathrm{a}}(388)$ & $369.15 \pm 0.87$ (196) \\
\hline 2002 & $722.04 \pm 7.61(211)$ & $871.80 \pm 7.56(211)$ & $1.04 \pm 0.01^{\mathrm{abc}}(428)$ & $368.04 \pm 0.83(211)$ \\
\hline 2003 & $719.91 \pm 11.63(73)$ & $870.31 \pm 11.54(73)$ & $1.02 \pm 0.01^{\mathrm{a}}(232)$ & $367.47 \pm 1.27(73)$ \\
\hline 2004 & $719.84 \pm 7.68(217)$ & $869.54 \pm 7.63$ (217) & $1.05 \pm 0.01^{\mathrm{abc}}(405)$ & $368.08 \pm 0.83(217)$ \\
\hline 2005 & $734.87 \pm 7.63(212)$ & $884.16 \pm 7.57(212)$ & $1.03 \pm 0.01^{\mathrm{a}}(418)$ & $369.06 \pm 0.83(212)$ \\
\hline 2006 & $723.39 \pm 7.69(190)$ & $873.84 \pm 7.64(190)$ & $1.05 \pm 0.01^{\mathrm{abc}}(411)$ & $368.52 \pm 0.84(190)$ \\
\hline 2007 & $724.96 \pm 9.04(140)$ & $874.15 \pm 8.98(140)$ & $1.03 \pm 0.01^{\mathrm{ab}}(327)$ & $368.08 \pm 0.98(140)$ \\
\hline Season & NS & NS & NS & NS \\
\hline winter (Dec-Feb) & $726.84 \pm 2.20(1883)$ & $876.84 \pm 2.18(1883)$ & $\begin{array}{c}1.05 \pm 0.00 \\
(3984)\end{array}$ & $368.22 \pm 0.24(1883)$ \\
\hline spring (March-May) & $721.20 \pm 9.57(93)$ & $869.95 \pm 9.50(93)$ & $1.05 \pm 0.01(202)$ & $368.74 \pm 1.04(93)$ \\
\hline Sex & & & NS & \\
\hline Male & - & - & $1.04 \pm 0.00(2213)$ & - \\
\hline Female & - & - & $1.05 \pm 0.00(1973)$ & - \\
\hline
\end{tabular}

Means with same superscript do not differ significantly 
However significant effect of season on litter size was reported by Molina et al., (1991) in Manchega sheep, Shelton et al., (1991) in Rambouillet and Ferda et al., (2009) in Fat tailed sheep. The effect of sex was nonsignificant on litter size. No literature was available as concerned regarding the nonsignificant effect of sex on litter size. However significant effect of sex on litter size was reported by Trejo et al., (1990) in Chalma sheep, Molina et al., (1991) in Manchega sheep and Shelton et al., (1991) in Rambouillet. The effect of year of birth was non-significant on inter lambing period. Similar findings were reported by Sinha (1996) in Muzaffarnagri and its crosses with Dorset and Suffolk. On contrary significant effect of year of birth on inter lambing period was reported by Narayanswamy (1978) in Bannur sheep, Iniquez et al., (1991) in Sumatran sheep, Kabuga and Akowuah (1991) in Djallonke and Sahel sheep, Khan et al., (2002) in Rambouillet and Kaghani sheep, and Babar and Javed (2009) in Rambouillet.

The effect of season of birth was nonsignificant on inter lambing period. Similar findings were reported by Sinha (1981) in Muzaffarnagri and their crosses with Dorset and Suffolk. On contrary significant effect of season of birth on inter lambing period was reported by Trejo et al., (1990) in Chalma sheep, Iniquez et al., (1991) in Sumatran sheep, and Khan et al., (2002) in Rambouillet and Kaghani sheep.

\section{Acknowledgements}

Authors are thankful to the in-charge and staff of Government Sheep Breeding and Research Farm, Reasi, Jammu for providing facilities and help for the present study.

\section{References}

Arora, C.L., Acharya, R.M., Kishore Kamal., Rawat, P.S., Uppal, P.K., Sharma, M.M., Gaur, D. and Mehta, B.S. 1978. Evaluation of performance of the new strains of sheep evolved at C.S.W.R.I and development of suitable selection criteria for their further improvement. Annual Report, Central Sheep on Wool Research Institute, Avidanagar, 7-12.

Babar, M.E. and Javed, K. 2009. Non genetic factors effecting reproduction and growth traits of fine wool breeds. J Agri. Sci., 34(3): 225-231.

Bohra, S.D.J. 1993. A note on wool production characteristics of fine wool breeds. Livestock Adivsor, 8(11): 27-28.

Dickson, W.F. and Lush, J.L. 1933. Inbreeding and the genetic history of the Rambouillet sheep. American J. Heredity, 24: 19-33.

Duguma, G., Schoeman, S.J., Cloete, S.W.P. and Jordaan, G.F. 2002. Genetic and environmental parameters for productivity in Merinos. South Africa J. Ani. Sci., 32: 154-159.

Ekiz, B., Ozcan, M., Yilmaz, A. and Ceyhan, A. 2005. Estimates of phenotypic and genetic parameters for ewe productivity traits of Turkish Merino sheep. Turkey J. Vet. Ani. Sci., 29: 557-564.

Ferda Koycegiz, Ebru Emsen, Carlos Alcibiades Gimenez Diaz and Muzeyyen Kutluca. 2009. Effects of Lambing Season, Lamb Breed and Ewe Parity on Production Traits of Fat Tailed Sheep and Their Lambs. J. Ani. Vet. Adv., 8(1): 195198.

Gabina, D.E., Urarte, Z.J., Arran, F., Arrese, and Sierra, I. 1990. Factors affecting variations in fertility of Lacha ewes. Ani. Breed Abstract, 59(3): 1799.

Gonzalez, L., Espejo, J.M., Diaz, A., Serranogarrido, and Avarez Martinez, J. 1986. Increasing lambing frequency by means of techniques for controlling the oestrus cycle in Merino and Merino $\times$ Romanov ewes. Ani. Breed Abstract, 55(8): 503

Harvey, W.R. 1990. User guide for LSMLMW and MIXMDL package mixed model least squares and maximum likelihood computer programme. PC-2 version Mimeograph Colubia, Ohio, USA

Hultz, F.S. and Hill, J.A. 1931. Range Sheep and Wool in the Seventeen Western States, Wiley New York. 
Iniquez, L., Sanchez, U. and Ginting, S. 1991. Productivity of Sumatran sheep in a system integrated with rubber plantation. Ani. Breed Abstract, 61(11): 7574.

Jain R.S., Qureshi, M.I. Joshi, S. 2000. Genetic studies on greasy fleece yield in Rambouillet sheep in the arid region of Rajasthan. Indian Vet. J., 77: 317-320.

Jain R.S., Qureshi, M.I., Khan, F.H. and Tripathi, G.S. 2001. Factors effecting first fertile service in Rambouillet sheep. Indian Vet. J., 78: 547-548.

Kabuga, J.D. and Akowuah, F. 1991. Reproductive performance of Djallonke $\times$ Sahel Crossbred ewes in Ghana. Small Ruminant Res., 5(3): 245-254.

Kaul, S.K. 1979. Genetics of reproductive traits and their relationships with blood groups and body weight in Muzaffarnagri, Ph.D. Thesis, Agra University Agra.

Khan, M.A, Parvez, M., Rashid, S. and Faisal, M. 2002. Genetic and non genetic factors effecting reproductive performance of Rambouillet sheep. Sarhad J. Agri., 22(4): 125-3138.

Kramer, C.R. 1957. Extension of multiple range tests to group correlated means. Biometrics, 13: 13-18.

Lehnherr, R. 1990. Population genetic analysis of reproductive traits in 4 Swiss breeds of sheep. Ani. Breed Abstract, 58(10): 6677.

Malik, R.C., Singh, R.N. and Mehta, B.S. 1978. Effect of season of birth on growth and subsequent reproduction in crossbred sheep. Indian Vet. J., 55: 707-712.

Matos, C.A., Thomas, D.L., Gianola, D., Tempelman, R.J. and Young, L.D. 1997.Genetic analysis of discrete traits in sheep using linear and nonlinear models: I. Estimation of genetic parameters. $J$. Ani. Sci., 75: 76-87.

Mokhtari M.S., Rashidi, A. and Esmailizadeh, A.K. 2010. Estimates of Phenotypic and
Genetic Parameters for Reproductive Traits in Kermani Sheep. Small Ruminant Res., 88(1).

Molina, A.L., Gallego, J.I., Perez, and Bernabeu, R. 1991. Growth of Manchega lambs in relation to body condition of dam season of birth, type of birth and sex. Animal Breed Abstract, 60(4): 2147.

Narayanswamy, M., Balaine, D.S. and Balbir Singh 1976. A note on studies of age at first lambing and lambing interval in Bannur (Mandya) sheep. Indian J. Ani. Sci., 46(11): 4749.

Shaoqi Rao. 1997. Genetic Analysis of sheep discrete reproductive traits using simulation and field data. Ph.D Thesis of Virginia Polytechnic Institute and State University.

Shelton, M., Willingha, T., Hompson, P. and Roserts, E.M. 1991. Influence of docking and castration on growth and carcass traits of fat-tail Karakul, Rambouillet and crossbred lambs. Small Ruminant Res., 4(3): 235-243.

Sinha, N.K. and Singh, S.K. 1996. Genetic and phenotypic parameters of body weights and wool yield in Muzzafarnagri sheep. National seminar on sheep and goat production and utilization, CSWRI Avikanagar Rajasthan. Abstracts of Contributory Papers, 2.

Tamu, D. 1980. Studies on reproductive performance of Russian Merino and Rambouillet ewes under semi-arid conditions of Rajasthan. Term Paper in Sheep Husbandry and Wool technology CSWRI, Avikanagar.

Trejo, G.A., Perez, P.Y., Gonzales, D.F. and Frey, S.E. 1990. Some production and reproductive parameters in Pellibuey ewes in a commercial flock at Chalma Mexico State. Ani. Breed Abstract, 59(1): 335.

\section{How to cite this article:}

Khan, N.N., N. Assad, Nishant Kumar, D. Chakraborty, Aadil Ayaz, Aarif Ali, Mashooq Ahmad Dar and Suheel Yousuf Wani. 2017. Non-Genetic Factors Effecting Reproduction Traits in Rambouillet Sheep. Int.J.Curr.Microbiol.App.Sci. 6(8): 3698-3704. doi: https://doi.org/10.20546/ijcmas.2017.608.446 